\title{
Peroxide oxidation processes and enzyme activity of the antioxidant system in the organism of rabbits of the New Zealand breed
}

\author{
Svitlana Tsekhmistrenko, \\ Nataliia Rol*, \\ Maksym Fedorchenko \\ Department of Chemistry, \\ Faculty of Biotechnology, \\ Bila Tserkva \\ National Agrarian University, \\ Sq. Soborna 8/1, \\ Bila Tserkva 09100, Ukraine
}

\begin{abstract}
The study is devoted to the study of the flow of peroxidation processes in various organs and tissues of the body of rabbits of the New Zealand breed in the age aspect. We used blood plasma and homogenate of the brain, the heart, the liver, and the longest back muscle selected after slaughter, from birth to 90-day-age at intervals of 15 days. The content of total lipids and secondary lipid peroxidation products - TBA-reactive substances and enzymes of the antioxidant system were thoroughly studied in the prototype. The presence of high content of common lipids and TBA- reactive substances in blood plasma and liver tissues of rabbits at one day and 15 days of age was established, which pointed to active process of peroxide oxidation of lipids. An increase in the content of TBA- reactive substances was noted in the heart of rabbits with $2.24 \mathrm{mmol} / \mathrm{g}$ tissue in one-day animals to $4.85 \mathrm{mmol} / \mathrm{g}$ tissue in 90-day-old animals.
\end{abstract}

Keywords: lipid peroxidation, antioxidant enzymes, plasma, heart, rabbit

\section{INTRODUCTION}

Formation of free radicals in the body, as well as the process of peroxide lipid oxidation (LPO), refers to the physiological processes that physiologically occur in the body under normal conditions and are necessary for the performance of such physiological functions as pinocytosis, phagocytosis, regulation of permeability of membranes, conduction of nervous excitation, etc. The functioning of the antioxidant system (AOS), which helps to provide antioxidant homeostasis in the body, regulates the course of processes of free radical oxidation in the body. Since the course of free rad-

\footnotetext{
*Corresponding author. Email: natalka290991@gmail.com
}

ical processes in the cells and tissues of the body largely determines the peculiarities of growth, development, the nutritional value of meat, and reflects the adaptive ability of rabbits to mobilize their body to loads of endogenous and exogenous nature, this work is of scientific and practical interest (Adzhiev et al., 2017). The requirements of today lead to a search for new means for raising the productivity of animals. In the conditions of intensification of industrial methods of growing farm animals, in particular rabbits, the use of vitamin and fodder supplements that affect various links of metabolic processes and allow them to receive products of higher quality and in greater quantity is effective. The directional effect on the processes of free radical oxidation is necessary in 
order to reduce the amount of free radicals and to increase the activity of the antioxidant defence system.

\section{MATERIALS AND METHODS}

The study addressed the process of lipid peroxidation oxidation and the activity of enzymes of the antioxidant defence system in the organs and tissues of rabbits of the New Zealand breed in the age dynamics. Research was carried out at the "Gregut" Ltd., Fastivsky District, Kyiv Region, and at the Laboratory of Biochemical and Histochemical Research Methods of the Bila Tserkva National Agrarian University. During the research, the principles of bioethics, legislative norms and requirements in accordance with the provisions of the "European Convention on the Protection of Vertebrate Animals Used for Research and Scientific Purposes" (Strasbourg, 1986) and the "General Ethical Principles of Animal Experiments" adopted by the First National Congress on Bioethics (Kyiv, 2001). Materials for research were blood plasma, and homogenate from the tissues of the brain, the heart, the liver, and the longest back muscle of the rabbits of the New Zealand breed, which were obtained after slaughter of animals, from birth to 90 days of age at intervals of 15 days. Five animals of each age group were used for research. The homogenate was obtained by triturating the prototypes in a Potter-Elveyem homogenizer at the rate of $7 \mathrm{mg}$ tissue $/ 0.3 \mathrm{ml}$ $0.9 \% \mathrm{NaCl}$. The intensity of the LPO processes was determined by the content of common lipids (Kolb, 1972) and TBA-reactive substances (TBA-RS) (Andreeva et al., 1988), and the state of the AOS system with the activity of superoxide dismutase (SOD) (Chevari et al., 1985), catalase (Korolyuk et al., 1988), and glutathione peroxidase (GPO) (Moin, 1996).

The content of total lipids was determined by a method based on the ability of the interaction of products of decomposition of lipids, after their hydrolysis with sulphate acid, to interact with a phosphate-vanillin reagent to form a pink complex with a maximum absorption at a wavelength of $550 \mathrm{~nm}$. The number of total lipids was expressed in $\mathrm{g} / \mathrm{mg}$ tissue.

The content of TBA-reactive substances was determined by a method based on the fact that lipid peroxidation products, the main of which are malonic dialdehyde, react with 2-thiobarbituric acid at a high temperature in an acidic medium to form a trimethyl complex extracted with butanol and has maximum absorption at $535 \mathrm{~nm}$ wavelengths.

The activity of superoxide dismutase was determined by a method based on the ability of the enzyme to compete with nitrosine tetrazolium for superoxide anion radicals formed as a result of aerobic interaction of the reduced form of niconinamedinedine dinucleotide and phenazine methasulphate. As a result of this reaction, nitrosine tetrazolium is restored with the formation of hydrazine tetrazolium (nitroformasane). The concentration of the resulting hydrazine tetrazolium was determined by measuring the optical density of the reaction mixture at a wavelength of $540 \mathrm{~nm}$. The activity of SOD was expressed in U.D./g tissue.

The activity of catalase was determined by a method based on the ability of the hydrogen peroxide to form a stable stained complex with molybdenum salts, the intensity of which was measured on a spectrophotometer at a wavelength of $410 \mathrm{~nm}$. The intensity of the colouring of peroxide compounds of molybdenum depends on the amount of $\mathrm{H}_{2} \mathrm{O}_{2}$ in the solution. Catalase, decomposing hydrogen peroxide, reduces the intensity of the colour in the sample. Enzyme activity was expressed in $\mathrm{mcat} / \mathrm{mg}$.

The activity of glutathione peroxidase was determined from the rate of oxidation of glutathione in the presence of tertiary butyl peroxide. The concentration of reduced glutathione was determined colourimetrically before and after the reaction. The development of the colour reaction is based on the interaction of HSgroups with 5,5'-dithiobis-2-nitrobenzoic acid with the formation of a coloured product - thionitrophenyl anion. The content of the latter is directly proportional to the amount of HSgroups that reacted with the above-mentioned 
acid. The optical density was determined on a spectrophotometer at a wavelength of $412 \mathrm{~nm}$.

\section{RESULTS}

Lipids play an important role in shaping the mechanisms of adaptation of an organism to the environment. Consideration is given to the study of lipid metabolism in various organs and tissues of animals, since lipids are the main energy substrate and an integral part of cellular structures.

In the course of the studies performed on the plasma and brain, the heart, the liver, and the longest back muscle tissue, the content of total lipids was studied. From the data given in the Table 1 it is evident that on the 60th day of life, the content of total lipids in the tissues of the rabbit brain increased by $26.3 \%$ compared with the values of one-day-old rabbits. However, compared with the start of the experiment, there was a decrease in the content of total lipids on the 75th and the 90th days of life by $16.7 \%$ and $65.8 \%$, respectively. In the tissues of the heart, there was a decrease in the content of total lipids on the 15th, the 60th, and the 90th days of life of experimental animals by $26.4 \%, 38.5 \%$, and $47.8 \%$, respectively. It should be noted that in the longest muscle of the back, the content of total lipids increased throughout the trial period. Thus, in 60-day-old animals it was 2.7 times larger compared to one-day-olds, and 2.9 times higher on the 90th day. Such high rates can probably be explained by the func- tional significance of lipids in the body, as well as by the fact that lipids are deposited in muscle tissue with a decrease in physical activity.

In the course of research, it was found that from the first days of life the content of total lipids in rabbits' plasma has a tendency to increase and for 45 days was significantly higher - by $54.1 \%$ - compared with one-day-old animals. Slight fluctuations were observed during subsequent studies into 60-, 75-, and 90-day-old rabbits.

It was found that in the liver of one-day-old rabbits the content of total lipids had a slight increase in one-day-old rabbits. Later, there was a tendency for the content of total lipids to increase in 30- and 45-day-old rabbits. The maximum value of total lipid content in liver tissues of 60-day-old rabbits was significantly higher by $26 \%$ than in one-day-old animals. There was a tendency of a decrease in the content of common lipids in the liver tissues of 75 - and 90-day-old animals.

Establishing the content of TBA-reactive substances in the blood plasma also showed a certain tendency of increase, in particular, in of 1- to 45-day-old rabbits (Table 2). At the same time, there was a probable difference in the content of TBA-reactive substances in rabbit blood plasma on the 15th day: it was $36 \%$ higher than that of one-day-old animals.

A slight increase in the content of TBA- reactive substances is noted in the liver tissue of one-day-old rabbits. Subsequently, in 15and 30-day-old animals, there was a probable

Table 1. Content of total lipids in the organs and tissues of rabbits $(M \pm m, n=5)$

\begin{tabular}{c|c|c|c|c|c}
\hline $\begin{array}{c}\text { Age, } \\
\text { days }\end{array}$ & $\begin{array}{c}\text { Plasma, } \\
\text { g/dm }\end{array}$ & $\begin{array}{c}\text { Brain, mg/g } \\
\text { of tissue }\end{array}$ & $\begin{array}{c}\text { Heart, mg/g } \\
\text { of tissue }\end{array}$ & $\begin{array}{c}\text { Liver, mg/g } \\
\text { of tissue }\end{array}$ & $\begin{array}{c}\text { The longest back } \\
\text { muscle, mg/g of tissue }\end{array}$ \\
\hline 1 & $21.79 \pm 3.71$ & $16.81 \pm 1.76$ & $42.70 \pm 7.98$ & $26.83 \pm 0.77$ & $5.44 \pm 1.40$ \\
\hline 15 & $23.10 \pm 1.04$ & $18.55 \pm 2.08$ & $31.44 \pm 3.32$ & $25.30 \pm 0.90$ & $8.74 \pm 0.96$ \\
\hline 30 & $23.72 \pm 1.72$ & $15.50 \pm 4.93$ & $44.80 \pm 7.37$ & $27.64 \pm 1.03$ & $9.75 \pm 1.87$ \\
\hline 45 & $33.58 \pm 3.17^{* *}$ & $17.53 \pm 4.91$ & $49.12 \pm 4.84$ & $28.25 \pm 2.18$ & $10.65 \pm 1.26$ \\
\hline 60 & $16.23 \pm 3.02^{* *}$ & $21.24 \pm 5.17$ & $33.67 \pm 4.96$ & $33.82 \pm 2.71$ & $14.78 \pm 6.85$ \\
\hline 75 & $17.01 \pm 2.49$ & $14.00 \pm 2.29$ & $51.48 \pm 4.68$ & $27.97 \pm 1.25$ & $14.18 \pm 1.74$ \\
\hline 90 & $19.47 \pm 1.93$ & $5.74 \pm 0.71^{* *}$ & $26.85 \pm 2.97$ & $27.81 \pm 1.47$ & $15.56 \pm 3.61$ \\
\hline
\end{tabular}

Here and in the tables below: $-p \leq 0.05 ;^{* *}-p \leq 0.01 ;{ }^{* *}-p \leq 0.001$ - compared with preceding age period. 
Table 2. Content of TBA-reactive substances in the organs and tissues of rabbits $(M \pm m, n=5)$

\begin{tabular}{|c|c|c|c|c|c|}
\hline $\begin{array}{l}\text { Age, } \\
\text { days }\end{array}$ & $\begin{array}{c}\text { Plasma, } \\
\mathrm{mcmol} / \mathrm{dm}^{3}\end{array}$ & $\begin{array}{c}\text { Brain, } \mathrm{mcmol} / \mathrm{g} \\
\text { of tissue }\end{array}$ & $\begin{array}{c}\text { Heart, } \mathrm{mmol} / \mathrm{g} \\
\text { of tissue }\end{array}$ & $\begin{array}{c}\text { Liver, } \mathrm{mmol} / \mathrm{g} \\
\text { of tissue }\end{array}$ & $\begin{array}{l}\text { The longest back mus- } \\
\text { cle, } \mathrm{mmol} / \mathrm{g} \text { of tissue }\end{array}$ \\
\hline 1 & $4.82 \pm 0.25$ & $62.11 \pm 1.04$ & $2.24 \pm 0.15$ & $0.648 \pm 0.02$ & $19.59 \pm 0.35$ \\
\hline 15 & $6.55 \pm 0.44^{\star *}$ & $55.58 \pm 0.85^{\star \star}$ & $2.66 \pm 0.17$ & $0.446 \pm 0.07^{\star}$ & $23.24 \pm 0.77^{\star \star}$ \\
\hline 30 & $6.63 \pm 0.23$ & $54.01 \pm 1.27$ & $2.84 \pm 0.23$ & $0.194 \pm 0.04^{\star * *}$ & $23.09 \pm 0.59$ \\
\hline 45 & $6.85 \pm 0.64$ & $56.06 \pm 1.96$ & $3.26 \pm 0.45$ & $0.176 \pm 0.02^{* * *}$ & $23.81 \pm 0.44$ \\
\hline 60 & $5.85 \pm 0.38$ & $56.45 \pm 1.44$ & $4.79 \pm 0.49^{*}$ & $0.193 \pm 0.03^{* * *}$ & $23.15 \pm 0.43$ \\
\hline 75 & $6.39 \pm 0.17$ & $56.27 \pm 1.37$ & $4.82 \pm 0.25$ & $0.132 \pm 0.02^{\star * *}$ & $23.87 \pm 0.41$ \\
\hline 90 & $6.77 \pm 0.59$ & $55.04 \pm 0.67$ & $4.85 \pm 0.26$ & $0.117 \pm 0.01^{\star * *}$ & $23.36 \pm 0.68$ \\
\hline
\end{tabular}

decrease in this indicator relative to the previous age. At the same time, the content of TBAreactive substances in 15-day-old rabbits was probably 1.5 times lower and in 30-day-old rabbits - 3.3 times in relation to one-day-old rabbits. Later the probable decrease in the content of TBA-reactive substances continued in the liver tissues of 45-, 60-, 75-, and 90-dayold rabbits age. The content of TBA-reactive substances decreased 3.7 times in 45-day-old rabbits, 3.4 times in 60-day-olds, 4.9 times in 75-day-old rabbits, and, and 5.5 times in 90-day-old rabbits.

The content of TBA-RS in the rabbit brain decreased with age, indicating the activation of the glutathione link in the AOS system of the body. There was a significant $45.5 \%$ $(p \leq 0.05)$ increase in TBA-RS content on the 60 th day of the rabbits' life.
In the functioning of the antioxidant system, a special role belongs to enzymes-antioxidants, including superoxide dismutase and catalase.

The dynamics of superoxide dismutase activity in the organs and tissues of rabbits is presented in Fig. 1. On the 30th day, the activity of SOD in the tissues of the brain of experimental animals was reduced almost threefold, compared to one-day-old rabbits. In the course of research, it was found that the highest activity of SOD was in the heart of one-day rabbits. However, on the 15th day, this figure was significantly $(p<0.05)-2.2$ times - lower than at the start of the experiment, and the lowest activity of the SOD was observed in 45- day-old rabbits.

There was no significant difference between SOD activity indices in the longest back muscle. The highest activity rate was observed in 60 -day-old rabbits, and by the 90th day the

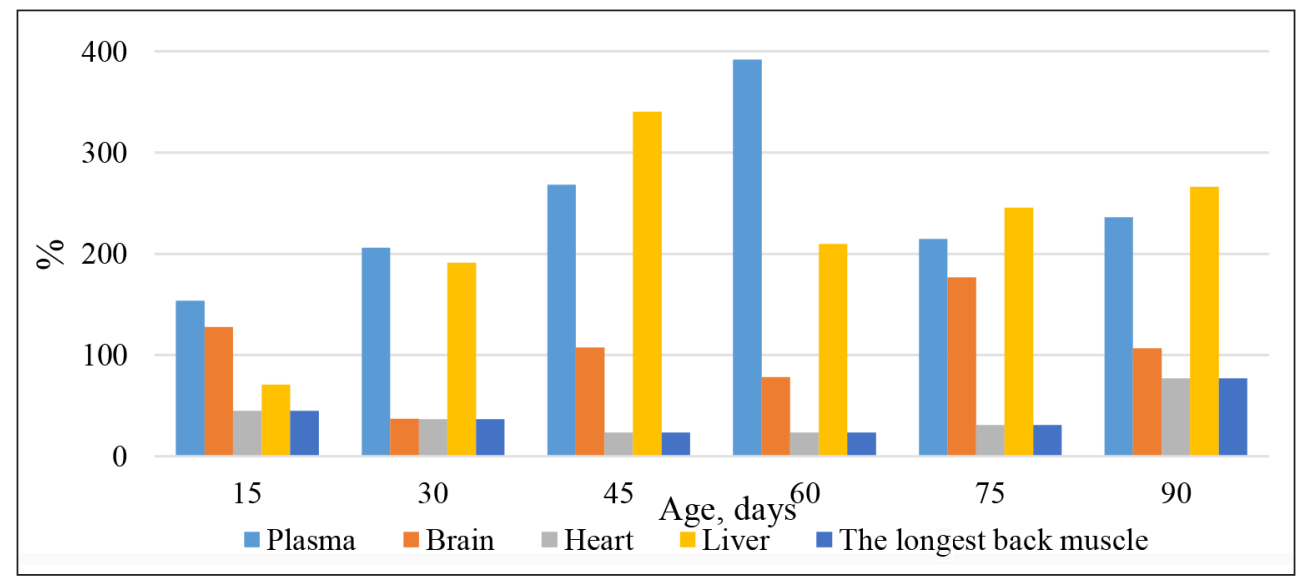

Fig. 1. Activity of superoxide dismutase in the organs and tissues of rabbits compared with one-day-old animals $(M \pm m, n=5)$ 
activity of SOD decreased by $10.8 \%$. The activity of catalase increased by $8.5 \%$ from birth to 30 -day age. In the period of 45- and 60-days, the activity of this enzyme was somewhat reduced, and, a significant $(p<0.05)$ increase of $10.4 \%$ in catalase activity was observed on the 75th day of the experiment.

In the blood plasma of 15-day-old rabbits an increase in activity of superoxide dismutase was registered, which, compared to one-dayold rabbits, was significantly higher, by $53.8 \%$.

Increasing activity of SOD was observed in rabbits of up to 60 days of age and amounted to $98.36 \pm 5.10$ U.D. $/ \mathrm{cm}^{3}$ during this period, which was believed to be 1.5 times higher than the previous age (45 days) and 3.9 times higher than in one-day-old animals.

The activity of superoxide dismutase in the liver tissues had a slight increase in oneday-old rabbits. In the liver of 30-day-old rabbits there was a tendency for the activity of SOD to increase, and in 45-day-old animals this indicator was of high value: it was 3.4 times $(p<0.001)$ higher compared to one-day-old animals. The tendency for the activity of superoxide dismutase to decrease was recorded in the liver tissue of 60-day-old rabbits.

During the study, the activity of catalase in liver tissues tended to increase in animals at one, 15, and 30 days of age (Fig. 2). In particu- lar, in 30-day-old rabbits, the activity of catalase was significantly higher by $4.5 \%$ compared with one-day-old animals. In the subsequent study periods (45-, 60-, 75-, 90-day-old), there was a certain tendency for the activity of this enzyme to decrease.

The activity of catalase in the brain on the 30th day of research was at a high level $-87.6 \%$ compared to one-day-old rabbits. The activity of catalase positively correlates with the number of TBA-reactive substances $(r=0.52)$.

In the tissues of the heart, slight fluctuations were observed in the activity of catalase. Thus, its highest activity was observed at the 45th day $-5.84 \pm 0.26$ cat/g of tissue, while the activity of the SOD was the lowest $-2.08 \pm 0.56$ U.D./g of tissue.

The level of glutathione peroxidase activity, which plays an active role in protecting the lysosomal membranes of cells from peroxide oxidation, also showed a tendency to increase in plasma of one-, 15-, 30-, 45-, and 60-day-old rabbits (Fig. 3). At the same time, the highest activity was recorded at 60 days of age. Activation of the enzyme in the blood of animals is possible only with the maintenance of a sufficiently high level of intracellular reduced glutathione (GSH), which plays a role not only in the reaction substrate, but also in the factor necessary for the permanent restoration of

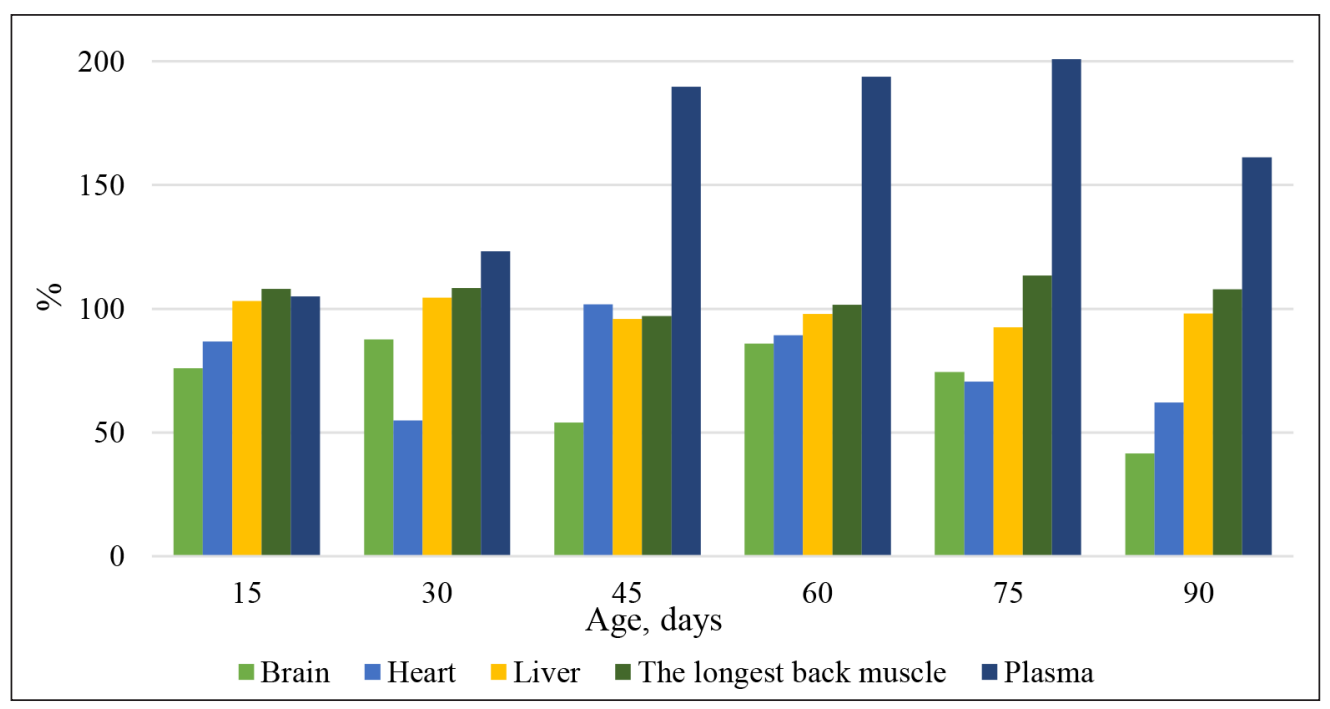

Fig. 2. Activity of catalase in organs and tissues of rabbits $(M \pm m, n=5)$ 


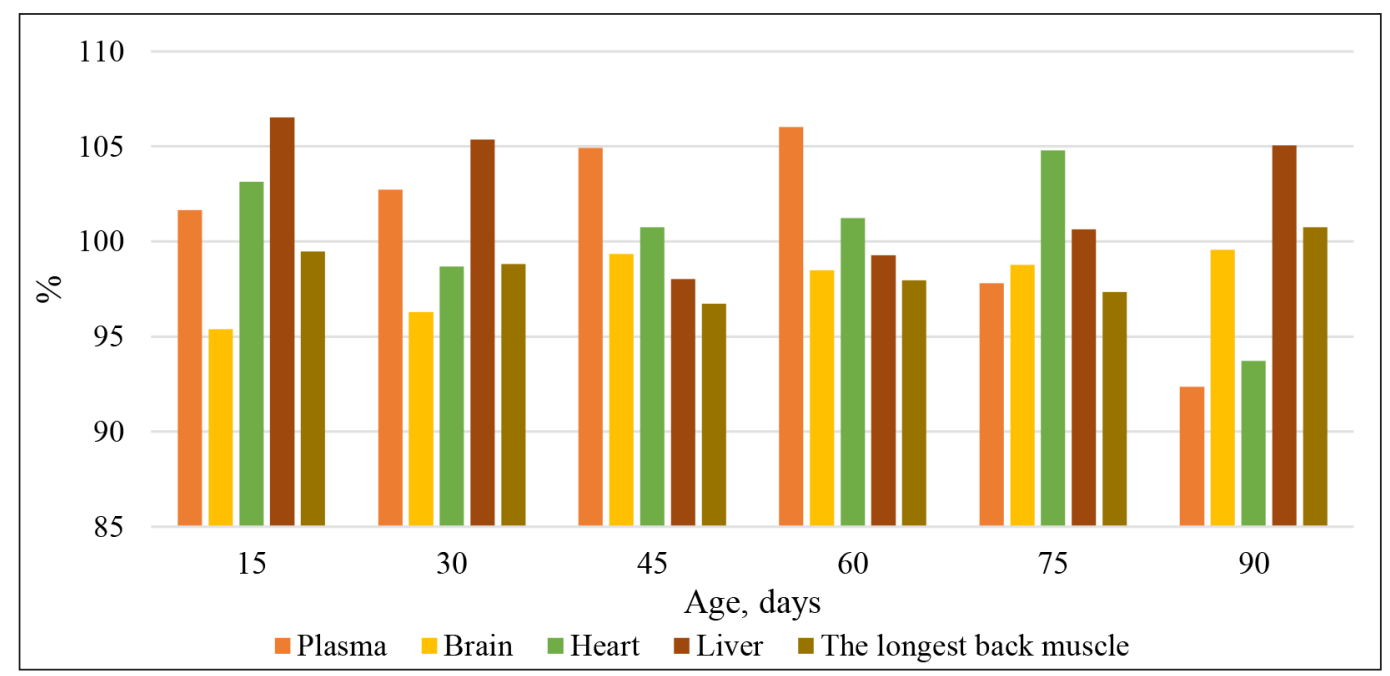

Fig. 3. Activity of glutathione peroxidase in the organs and tissues of rabbits $(M \pm m, n=5)$

the selenyl groups located in the catalytic centre of the enzyme oxidized by the glutathione peroxidase reaction.

Changes in the activity of glutathione peroxidase in liver tissues were characterized by a $6.5 \%$ increase in enzyme activity in 15-dayold rabbits and by $3.3 \%$ in 30-day-old rabbits compared with one-day-old animals. From 45 to 90 days of age, GPO values were characterized by a tendency towards a gradual increase and balanced activity.

During the experimental period, the activity of the GPO in the rabbits' brain was at a constant level and had slight fluctuations. A moderate correlation $(r=0.54)$ between the GPO activity and the content of TBA-reactive substances in the brain of New Zealand rabbits was established.

In the tissues of the heart of experimental animals, an increase of $1.2 \%$ and $4.7 \%$ in GPO activity was noted at 60 and 75 days of age, at respectively. But on the 90th day of life of the rabbits, the activity of the enzyme decreased by $11.8 \%$.

\section{DISCUSSION}

Peroxide processes play an important role in the functioning of all body systems. Any adaptive or pathological changes in the body occur with the participation of active forms of oxygen and the intensification of free radical oxidation of biosubstrates. Lipids play an important role in shaping the mechanisms of adaptation of an organism to the environment. The qualitative and quantitative composition of lipids in the tissues of the body largely depends on the intensity of free radical oxidation processes. The main target in these reactions is unsaturated fatty acids of membrane phospholipids (Takehiko et al., 2015; Gbore Francis et al., 2016). It is known, that the nature of changes in the content of lipids in the blood reflects the nature of their changes in the tissues (Tsekhmistrenko et al., 2015), so we investigated the content of total lipids in the plasma, the heart, the brain, the liver, and the longest back muscle of the rabbit in the age aspect. Increased levels of total lipids and TBA- reactive substances in plasma and liver tissue of one-dayold and 15-day-old rabbits indicated an active peroxidation process, which may be the result of a stressful reaction to the effects of environmental factors in the adaptive period of the young organism. It should be noted that the content of TBA-RS in the rabbit's brain decreased with age, indicating the activation of the glutathione link system of the AOS organism.

An important role in the processes of adapting the organism to the environment is played by the antioxidant system of organism protection. Its task is to provide a dynamic balance between the content of LPO products and the activity of antioxidant enzymes. 
One of the key enzymes for antioxidant defence is superoxide dismutase. Studies have shown that blood plasma of 60-day-old animals is characterized by high activity SOD. Further, the activity of the enzyme is reduced by $43 \%$. Probably such changes are caused by the interaction of this enzyme with free radicals, which is accompanied by a significant decrease in the products of lipid peroxidation oxidation. According to some authors, the activity of SOD correlates with the activity of catalase, since their main function is to neutralize superoxydanione radicals and hydrogen peroxide, which are formed as a result of the "loss" of an unpaired electron from the mitochondrial electron transfer chain (Tkáčová et al., 2017). In blood plasma and liver tissues of 60-day-old rabbits, there was an increase in the activity of catalase and glutathione peroxidase, which reflects the acquisition of stability of the system of antioxidant protection of the young organism.

\section{CONCLUSIONS}

In order to maintain the stock of rabbits and increase their productivity, it is necessary to accurately control the content of total lipids, TBA-reactive substances, and also the activity of enzymes of antioxidant protection (superoxide dismutase, catalase, glutathione peroxidase) in plasma and other vital organs and tissues.

Further research and study into the processes of peroxide oxidation of lipids and proteins and functioning of antioxidant protection system in the age dynamics are relevant.

Received 29 April 2018

Accepted 1 April 2019

\section{References}

1. Korolyuk MA, Ivanova AI. Metod opredeleniya aktivnosti katalazyi. Lab. delo. 1988; 1 : 16-9. Russian.

2. Moin VM. Prostoy i spetsificheskiy metod opredeleniya glutationperoksidazyi v eritrotsitah. Lab. delo. 1996; 12: 724-7. Russian.
3. Stalnaya ID, Garishvili TG. Metod opredeleniya malonovogo dialdegida s pomoschyu tiobarbiturovoy kislotyi. Sovremennyie metodyi v biohimii. Moskva: Meditsina, 1977: 66-8. Russian.

4. Chevari S, Chaba I, Sekey Y. Rol superoksiddismutazyi v okislitelnyih protsecsah kletki i metod opredeleniya ee $\mathrm{v}$ biologicheskih materialah. Lab. delo. 1985; 11: 678-81. Russian.

5. Kolb VG, Kamyishnikov VS. Klinicheskaya biohimiya. Minsk: Belarus, 1976: 150-4. Russian.

6. Takehiko U, Megumi S, Yuzuru N. The extracellular A-loop of dual oxidases affects the specificity of reactive oxygen species release. J Biol Chem. 2015; 290: 6495-506.

7. Adzhiev DD, Kalugin YuA, Balakirev NA. Antioksidantnaya sistema krolikov v rannem postnatalnom ontogeneze. Nefermentativnoe zveno antioksidantnoy zaschityi i produktyi perekisnogo okisleniya lipidov. Veterinariya, zootehniya i biotehnologiya. 2017; 4: 87-92. Russian.

8. Tsekhmistrenko SI, Fedorchenko MM. Vplyv vitaminno-mineralnoi dobavky na pokaznyky peroksydnoho okysnennia lipidiv $\mathrm{v}$ orhanizmi kroliv. Naukovyi visnyk LNUVMBT imeni S. Z. Gzhytskoho. 2015; 17; 1: 249-55. Ukrainian.

9. Gbore Francis A, Adu Olufemi A, Ewuola Emmanuel O. Protective role of supplemental vitamin $\mathrm{E}$ on brain acetylcholinesterase activities of rabbits fed diets contaminated with fumonisin $B_{1}$. Eur J Biol Res. 2016; 6(2): 127-34.

10. Tkáčová J, Angelovičová $\mathrm{M}$, Capcarová $\mathrm{M}$. The investigation of alfalfa effect on the activity of superoxide dismutase in chicken meat in dependence on time storage. Potravinarstvo Slovak Journal of Food Sciences. 2017; 11(1): 606-11.

11. Andreeva YaI, Kozhemyakin LA. Metodika opredeleniya malonovogo dialdegida. Lab. delo. 1988; 11: 41-3. Russian. 


\section{Svitlana Tsekhmistrenko, Nataliia Rol,} Maksym Fedorchenko

\section{NAUJOSIOS ZELANDIJOS VEISLĖS \\ TRIUŠIŲ PEROKSIDACIJOS PROCESAS \\ IR ANTIOKSIDACINĖS SISTEMOS \\ FERMENTINIS AKTYVUMAS}

\section{Santrauka}

Tyrimu siekta išanalizuoti peroksidacijos procesą ivvairaus amžiaus Naujosios Zelandijos veislès triušių organuose ir audiniuose. Tam buvo naudota kraujo plazma ir smegenų, širdies, kepenų bei ilgiausiojo nugaros raumens homogenatai skerdžiant gyvūnus 15 dienų intervalais nuo gimimo iki 90 dienų amžiaus. Buvo tirtas prototipo bendras lipidų ir antrinių lipidų peroksidacijos produktų - TBAreaktyvių medžiagų ir antioksidacinès sistemos fermentų - kiekis. Nustatyta didelè bendrų lipidų ir TBA-reaktyvių medžiagų koncentracija 1-15 dienų amžiaus triušių kraujo plazmoje ir kepenyse patvirtina aktyvią lipidų peroksidaciją. Pastebètas ir TBA-reaktyvių medžiagų kiekio didejjimas triušių širdyse: 1 dienos gyvūno $-2,24 \mathrm{mmol} / \mathrm{g}$ ir 90 dienų $-4,85 \mathrm{mmol} / \mathrm{g}$.

Raktažodžiai: lipidų peroksidacija, antioksidaciniai fermentai, plazma, širdis, triušiai 